\title{
ROYAL ASIATIC SOCIETY PUBLICATIONS
}

ROYAL ASIATIC ، SOCIETY MONOGRAPHS.

Vols. XX-XXI.

A Study in the Economic Condition of Ancient India. By DR. PRAN NATH. 1929. Price 12s. 6d.

The Kumzari Dialect of the Shihuh Tribe, Arabia, and a Vocabulary. By Bertram Thomas. 1930. Price 2s. 6d.

\section{PRIZE PUBLICATION FUND. Vols. XIII-XIV.}

A Guide to Ismaili Literature. By W. IVANOw. 1933. 9s.

Women in the Aiyam al-Arab. By I. LICHTENSTÄDTER. 1935. 5s.

ORIENTAL TRANSLATION FUND.

Vols. XXXI and XXXIII.

Vicitrakarnikāvadānoddhrta. Nevãri Text and Translation. Edited by Dr. HANS JórgensEN. 1931. 12s. $6 d$.

Purusa Pariks̄ā or Test of a Man. By G. A. GRIERSON. 1935. 12s. 6d.

\section{JAMES G. FORLONG FUND. Vols. X-XV.}

Ta'rikkh-i-Jahān-Gushāy of Juwayni, Vol. III, Facsimile of MS. dated A.H. 690, belonging to Wahid-ul-Mulk. With Introduction by Sir E. Denison Ross. 1931. 7s. 6 d.

Dialogues in the Eastern Turki Dialect on Subjects of Interest to Travellers. By R. O. WINGATE and E. Denison Ross. 1934. 4s. $6 d$.

Phonetic System of Ancient Japanese. By S. YOSHITAKE. 1934. 6s.

An Introduction to Colloquial Bengali. By W. SutToN PAGE. 1934. 10s. 6d.

From Balavadbodha to Upadesamala. By T. N. DAve. 1935. 10s. 6d.

Balti Grammar. By A. F. C. READ, Central Asian

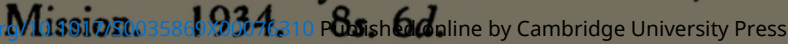




\section{ROYAL ASIATIC SOCIETY \\ OF \\ GREAT BRITAIN AND IRELAND, \\ 74 Grosvenor Street, W. 1. \\ SPECIAL NOTICE.}

The JOURNAL of the ROYAL ASIATIC SOCIETY is published quarterly. It is frequently illustrated and it contains Original Articles on the Languages, the Archæology, the History, the Beliefs and the Customs of the East.

Each quarter the principal books published on Oriental subjects are reviewed.

Acknowledgment is made in the Journal of presentations of books and pamphlets to the Society, which endeavours to publish reviews of them. It cannot, however, undertake to do this in all cases; neither can it return such as are not reviewed.

The Annual Subscription to the Society is THREE GUINEAS for Resident Members (except in the case of Ministers of Religion, Teachers of certain Oriental Subjects or Officials in certain Museums and Libraries, when the Council may reduce this subscription to Two Guineas), TWO GUINEAS for Non-resident Members residing in the British Isles, and THIRTY SHILLINGS for Non-resident Members residing abroad.

Each Member, whose Subscription for the current year has been paid, receives the Journal post free, has the use of the Library at the Society's rooms, and admission to the meetings of the Society. Three-guinea Subscribers may borrow books. Two-guinea Subscribers may be allowed to borrow books on payment of an additional fee to be determined by the Council.

Libraries and persons who are not Members may obtain the Journal post free by paying a Subscription of Two Pounds Eight Shillings a year in advance direct to the Secretary. The price of each part separately is Fifteen Shillings.

\section{NOTICE TO MEMBERS AND STUDENTS.}

Teas can be supplied by the Caretaker at a small charge. 